\title{
Antimicrobial activities and skin barrier improvement effect of Eruca sativa extract
}

\author{
Bora Kim ${ }^{1}$, Hyun-Soo Kim ${ }^{2 *}$ \\ ${ }^{1}$ Division of Biomedicinal Chemistry and Cosmetics, Mokwon University, Daejeon 35349, Korea \\ ${ }^{2}$ Department of Food science and Technology, Jungwon University, Goesan 28024, Korea
}

\section{루꼴라(Eruca sativa) 추출물의 항균활성과 피부장벽 개선 효과}

\author{
김보라 ${ }^{1} \cdot$ 김현수 $^{2 *}$ \\ ${ }^{1}$ 목원대학교 생의약화장품학부, ${ }^{2}$ 중원대학교 식품공학과
}

\begin{abstract}
Eruca sativa is a rocket plant and a member of the Brassicaceae, which is considered to be an important chemo-preventive plant family. Although Eruca sativa has positive biological effects, the effect of Eruca sativa extract (ES) on improvement of skin barrier function has not been reported. In this study, we investigated the applicability of functional materials by examining a variety of physiological activities of Eruca sativa extract. ES showed anti-microbial activities against Bacillus subtilis, Escherichia coli, and Candida albicans. In particular, antimicrobial activities of ES against $B$. subtilis was the highest. Additionally, immunohistochemical analysis of protein marker related to keratinocyte differentiation was determined. The treatment by ES $(50 \mathrm{mg} / \mathrm{L})$ showed a significant increase of involucrin expression compared with treatment by $0.1 \%$ DMSO as a control in skin equivalents, the ES-treated group showed similar level in the expression of involucrin compared to the group treated with the same concentration of WY14643 in EpiDerm ${ }^{\mathrm{TM}}$, a three-dimensional model of skin equivalents. These results indicate that ES promotes the expression of protein related to barrier properties of the skin. Therefore, ES may be an effective ingredient for skin barrier improvement.
\end{abstract}

Key words : Eruca sativa, antimicrobial activity, involucrin

\section{서 론}

사람의 피부는 진피(dermis)와 표피(epidermis)로 구성되 고 표피는 지질을 주로 생성하고, 콜라겐은 실질적으로 합 성하지 않는 각질형성세포(keratinocyte)로 주로 구성되어 있어 특히, 피부의 최외각에 위치하고 있는 표피는 외부의 다양한 물리적, 화학적 및 기계적 자극에 대한 방어와 피부 를 통한 체내 수분의 과도한 발산을 막는 보호 기능을 수행 하고 각질형성세포로 구성된 각질층이 정상적으로 형성되

*Corresponding author. E-mail : hyun1006@jwu.ac.kr Phone : 82-43-830-8616, Fax : 82-43-830-8679

Received 15 November 2016; Revised 27 December 2016; Accepted 28 December 2016.

Copyright (c) The Korean Society of Food Preservation. All rights reserved.
고 유지됨으로써 가능하다 $(1,2)$. 각질형성세포는 표피최하 층(stratum basale)에서 지속적으로 증식하던 기저세포 (basal cell)가 각질층(stratum corneum)으로 이동하면서, 단 계적으로 형태 및 기능상의 변화를 거치며 형성된 세포이 며, 일정 기간이 지나면 오래된 각질형성세포는 피부에서 탈락되고, 표피 최하층으로부터 올라온 새로운 각질형성세 포가 그 기능을 대신하는 표피 분화(epidermis differentiation) 또는 각화(keratinization)의 과정을 반복하게 되며 각질형성 세포는 천연보습인자(natural moisturizing factor, NMF)와 세라마이드, 콜레스테롤 및 지방산과 같은 세포 간 지질을 생성하여, 각질층이 외부와의 차단층 역할을 하게 됨으로 써 피부장벽(skin barrier)로서의 기능을 보유하게 된다(3). 피부장벽(skin barrier)은 지속적인 외부 자극에 의해 손상 되어 피부건조증, 아토피 등의 피부질환이 유발되는데 현 재 화장품에서 손상된 장벽을 보충하기 위해 보습제, 세라 
마이드 등 증상완화를 위한 물질을 사용할 뿐 피부항상성 기전에 근거한 근본적인 효능 물질 개발은 미미한 상황이다 (4).

Eruca sativa는 루꼴라(rucola)로 불리우며 피자같은 이탈 리아 요리에 많이 쓰이는 채소로 프랑스어로 로켓(rocket), 영어로는 아루굴라(arugula)라고 하는데, 로켓은 프랑스어 인 로케트(roquette)에서 유래한다. 고대 로마에서 루꼴라의 잎과 씨를 소중히 여겼으며 씨는 기름에 향을 내는데 사용 하였으며 잎과 꽃, 씨앗을 모두 식용하는데 맛이 고소하고 쌉싸름하고 머스터드와 같이 톡 쏘는 매운 향이 있는 것이 특징이고 비타민 $\mathrm{C}$, 칼륨의 함유량이 풍부하여 건강식, 미 용채소로도 많이 알려져 있다(5). 특히, 잎은 잘 빻아서 상처 난 곳, 아픈 관절, 빼가 부러진 곳에 치료 목적으로도 사용되 었다고 전해진다. 고대문헌에 보면 전갈 독 치료, 체내 기생 충제거, 얼굴피부의 spot제거, 식초와 함께 얼굴 잡티 제거, 흥터/멍 축소, 루꼴라 샐러드를 다져서 눈에 바르면 시력회 복 등 혈액순환을 도와 몸을 덥게 하고 에너지를 충전시키 며 이뇨와 소화를 돕는다는 보고(6)가 있는 등 예로부터 많은 효능이 있으며 이에 활용을 하고 있음을 보여준다. 또한, 본 연구자들의 선행연구에서 루꼴라 추출물에 대한 항산화 활성 및 멜라닌 생성 저해로 인한 피부미백 관련 기능성 소재로서의 가능성을 제시하였다(7). 본 연구에서 는 루꼴라 잎 추출시료를 가지고 항균시험과 인공피부를 활용한 피부장벽 기능 개선시험을 비롯한 피부효능 개선 시험을 조사하여 기능성 소재로서의 개발 가능성을 추가로 검토하고자 하였다.

\section{재료 및 방법}

\section{실험재료}

루꼴라(Eruca sativa) 잎은 가락동 농수산물 시장에서 구 입하여 사용하였다. 신선시료 30-40 g에 에탄올 $200 \mathrm{~mL}$ 를 첨가하고 용매추출장치(ASE300 Accelerated Solvent Extractor, Dionex Corporation, Sunnyvale, CA, USA)를 이용 하여 $50^{\circ} \mathrm{C}, 1,500 \mathrm{psi}$ 에서 20 분 동안 추출하였다. 이후 건조 기(Modul spin 40, Biotron Corporation, Marysville, WA, $\mathrm{USA}$ )에서 $40^{\circ} \mathrm{C}$ 에서 24 시간 동안 건조하고 실험에 사용하 였다.

\section{항균활성 측정}

항균효과는 agar disc diffusion방법(8)을 이용하여 측정 하였다. 즉, 시료액을 $0.22 \mu \mathrm{m}$ membrane filter로 여과하여 제균하고 멸균된 paper disc에 흡수시킨 후 시험용 평판배지 표면에 놓아 밀착시키고 각 균주(Bacillus subtilis, Escherichia coli, Candida albicans 분양기관: KCTC 생물자원 센터) 의 배양조건에 따라 24-48시간 동안 배양한 다음 paper disc
주위의 clear zone 및 inhibition zone의 크기로 항균성을 조사하였다. 또한, 시간별로 항균작용이 어떤 변화를 보이 는지 알아보기 위해 broth dilition 방법으로서 time-curve를 작성하였다. 선행연구(7)에서 세포독성이 나타나지 않으며 여러 생리활성 효과를 보인 농도인 루꼴라 추출물 최종농도 가 $50 \mathrm{mg} / \mathrm{L}$ 이 되도록 맞추기 위하여 각각 균주 배양액 100 $\mathrm{mL}$ 에 $5 \mathrm{mg}$ 으로 처리한 후, 일정 시간별로 배양액을 채취하 였다. 채취한 배양액을 십진희석법으로 희석하고 각각 균 주평 판배지에 접종하여 배양한 후, 생성되는 군락(colony) 의 수를 측정하고 colony forming unit(CFU)/mL로 환산하 였다.

\section{면역조직화학 분석}

케라티노사이트(Keratinocyte) 분화에 관련된 단백질인 인볼루크린(involucrin) 단백질 발현에 대한 루꼴라 추출물 의 영향을 분석하기 위하여 인공피부 실험을 시행하였다. MatTek Corporation(Ashland, MA, USA)에서 구입한 EpiDerm $^{\mathrm{TM}} 3$ 차원 피부모형 모델을 EPI-100-New maintenance medium(NMM, MatTek Co.)에서 24시간동안 안정화시킨 후 DMEM 배지(Gibco-BRL/Life Technologies, Grand Island, NY, USA)에서 배양하였다. 선행연구(7)에서 세포독 성이 나타나지 않으며 여러 생리활성효과를 보인 농도 50 $\mathrm{mg} / \mathrm{L}$ 기준으로 맞추어 루꼴라 추출물을 처리하였다. 12 시 간 처리 후에 인공피부를 면역조직화학 분석을 위해 수확하 였다. 인공피부 조직을 파라핀에 고정시키고 $60^{\circ} \mathrm{C}$ 에서 1 시 간 동안 정치시킨 후 자일렌(xylene)으로 10 분 동안 2회 반복 처리 및 $100 \%$ 에탄올로 5 분 2 회 반복, $70 \%$ 에탄올로 5 분 2회 반복 후 Tris-buffered saline(TBS)에서 10 분 동안 배양하였다. 배양 후, $3 \%$ 과산화수소에 30 분 동안 정치시키 고 TBS 버퍼로 3 회 세척하였다. 세척 완료된 인공피부조직 을 1차 항체(rabbit anti-involucrin: 1:500, Santa Cruz Biotechnology, Carlsbad, CA, USA)를 1 시간 동안 $37^{\circ} \mathrm{C}$ 에서 처리하였다. 이후 10 분 간격으로 $\mathrm{TBS}$ 로 5 회 세척하고 2 차 항체(mouse anti-rabbit IgG-HRP: 1:5,000, Santa Cruz Biotechnology)로 1시간 동안 상온에서 반응시켰다. 이후 10 분 간격으로 $\mathrm{TBS}$ 로 5 회 세척하고 인공조직을 $\mathrm{DAB}$ chromogen(Dako, Glostrup, Denmark)이 포함된 3,3'diaminobenzidine(DAB)버퍼에 2 분 동안 정치시킨 후 증류 수를 넣어 반응을 종료하였다. 준비된 조직시료는 현미경 (Carl Zeiss Inc., Oberkochen, Germany)으로 관찰하였으며 이미지 정량분석 프로그램(image quantitative analysis software, NIH images, version 1.61)을 이용하여 분석하였다.

\section{통계처리}

모든 실험은 독립적으로 3회 반복 시행하고 실험결과는 평균표준편차로 표기하였으며, 통계적 유의성은 Student's $\mathrm{t}$-test로 하였으며 $\mathrm{p}$ 값이 0.05 미만일 때 통계적으로 유의하 
다고 판단하였다. 통계분석프로그램은 Prism v3.0 - statistical software(GraphPad Software, San Diego, CA, USA)을 사용 하였다.

\section{결과 및 고찰}

\section{루꼴라 추출물의 항균 활성}

루꼴라 추출물에 대한 항균활성 측정은 디스크 확산법 (Disc diffusion method)을 이용하였다. 시료를 Dimethyl sulfoxide (DMSO) $10 \mu \mathrm{L}$ 에 $10 \mathrm{mg}$ 이 되도록 만든 후, DMSO 만을 함유한 disc를 대조군으로 하고, 각 농도의 시료액을 포함한 disc를 시험균으로 광범위한 균들에 대한 항균효과 를 보기 위하여 그람양성균 대표로서 B. subtilis, 그람음성 균 대표로서 E. coli, 효모균 대표로서 특히, 무좀균으로 잘 알려진(9) C. albicans를 균일하게 접종된 배지위에 올려 놓고 $30^{\circ} \mathrm{C}$ 에서, E. coli 만 $37^{\circ} \mathrm{C}$ 에서 48 시간 동안 배양하여 disc주변의 투명환을 관찰하여 항균활성을 측정하였다(Fig. 1A). 대조군에서는 균의 증식이 억제되지 않았으나 루꼴라 추출물에 대하여는 항균활성이 나타났으며, 특히, 그람양 성균인 B. subtilis에 대한 항균활성이 가장 높게 나타났다. 또한, 선행연구에서 보고(7)한 바와 같이 루꼴라 추출물에 대한 세포독성이 없으며 생리활성 효과를 보인 시료농도로 서 최종농도가 $50 \mathrm{mg} / \mathrm{L}$ 가 되도록 처리한 후, 시간별로 각각 시험군에 대한 항균작용을 알아보기 위해, time curve를 작성하였다(Fig. $1 \mathrm{~B}$ ). 대조군의 경우 시간이 경과함에 따라
균의 증식에 변함이 없었으나 추출물 시료처리 경우는 배양 12 시간 경과 후, B. subtilis, E. coli, C. albicans 각각 대조군 에 대하여 $61.5 \%, 43.9 \%, 26.1 \%$ 의 증식 억제가 확인되었다. 즉, 모든 시험균의 증식이 억제됨을 확인 할 수 있었으며 Disc 확산법과 마찬가지로 그람양성균인 B. subtilis에 대한 증식억제 효과가 가장 높게 나타났다. 또한, 다른 천연소재 중 우수한 항균효과를 보고된 바(10) 있는 소라쟁이 에탄올 추출물에 대한 B. subtilis, E. coli 항균활성이 약하게 보이는 것과 비교하였을 때, 루꼴라 추출물(ES)의 높은 항균력으로 천연방부제 및 아토피 피부염 악화인자인 세균증식을 억제 (11)함으로써 피부염을 개선할 수 있는 천연물 기반의 소재 개발 가능성을 기대할 수 있을 것으로 생각한다.

인공피부 조직에서 루꼴라 추출물의 피부장벽 기능 향상 효과

피부장벽 기능 향상을 위한 케라티노사이트 분화에 관련 된 바이오마커로서 알려진 인볼루크린 발현에 대한 면역조 직화학 분석을 인공피부를 이용하여 시행하였다(12). 루꼴 라 추출물을 처리 $(50 \mathrm{mg} / \mathrm{L})$ 한 경우에 $0.1 \% \mathrm{DMSO}$ 로 처리 한 대조군에 비하여 인볼루크린 발현이 뚜렷하게 증가하였 으며 동일농도로 처리된 합성물질 WY14643과 비교하였을 때에도 비슷한 발현양상을 보여 주었다(Fig. 2). 본 연구에 양성 대조군으로 사용된 WY14643과 clofibrate등 합성화합 물들은 케라티노사이트 분화 증진에 영향을 주어 피부장벽 기능개선에 효과를 보이는 것으로 이미 알려져 있다 $(13,14)$. 따라서 본 연구자들이 최근에 루꼴라 추출물이 독

$\mathbf{A}$

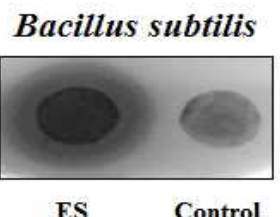

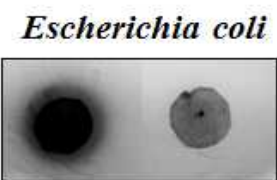

ES
Control

\section{Candida albicans}

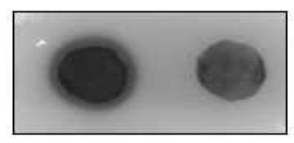

ES

Control
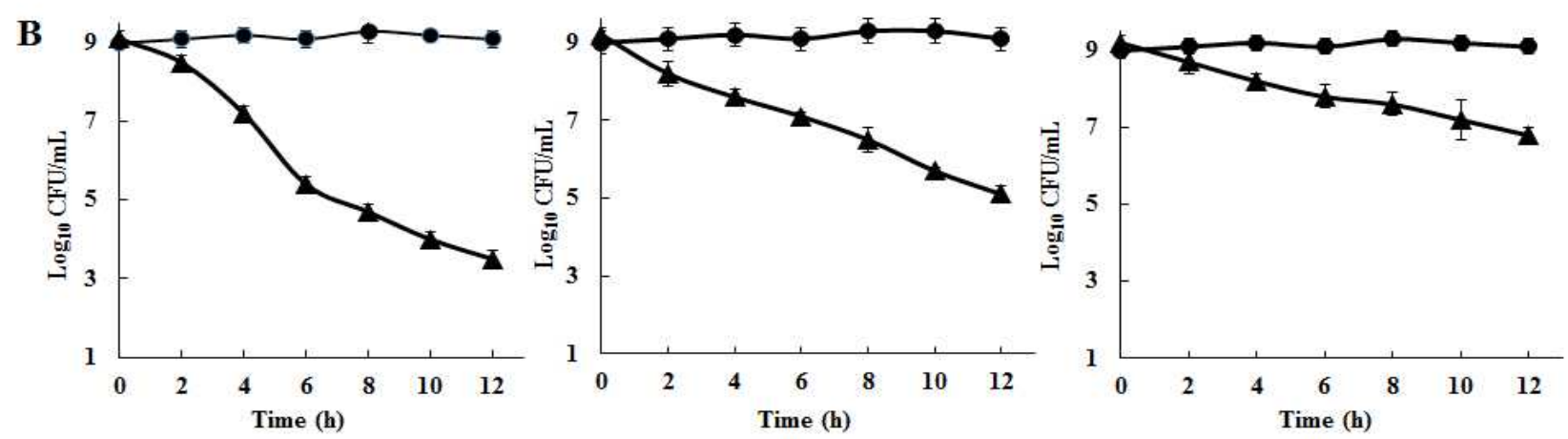

Fig. 1. Anti-microbial effect of Eruca sativa extract (ES).

A, a clear zone was examined around paper disc. $10 \%$ DMSO was used as a negative control; B, time-curve of ES against $B$. subtilis, $E$. coli and $C$. albicans. $10 \%$ DMSO was used as a negative control (O) and ES was dissolved in $10 \%$ DMSO to a final concentration of $50 \mathrm{mg} / \mathrm{L}$ 
$0.1 \%$ DMSO

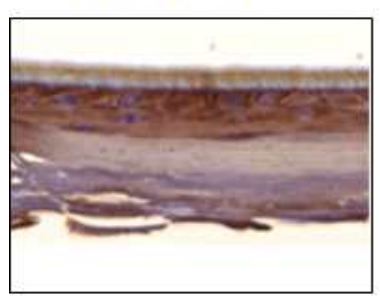

WY14643 $(50 \mathrm{mg} / \mathrm{L})$

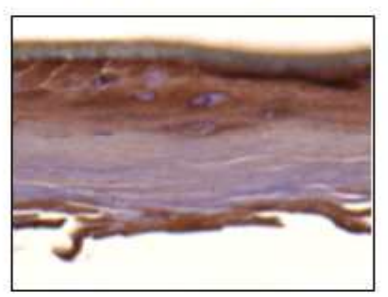

ES $(50 \mathrm{mg} / \mathrm{L})$

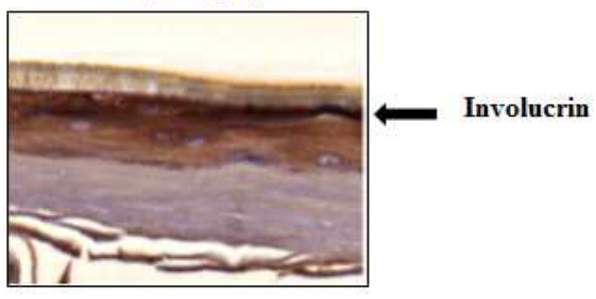

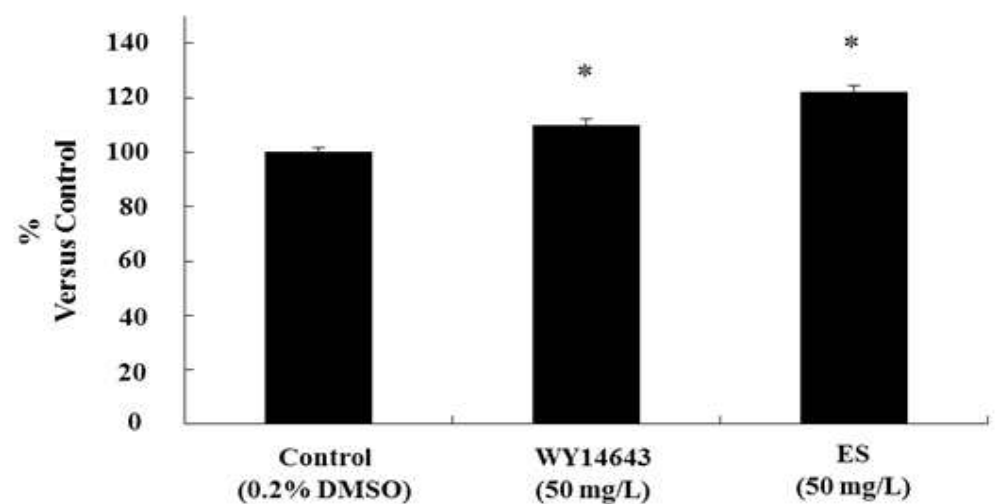

Fig. 2. Immunohistochemical analysis of involucrin in a 3D skin equivalent model.

WY14643 and Eruca sativa extract were treated at $50 \mathrm{mg} / \mathrm{L}$ concentration. $0.2 \%$ DMSO was treated as a control. The skin fragments were subjected to immunohistochemical analysis by using anti-involucrin antibody and observed by microscope. The area was analyzed by involucrin with image quantitative analysis software (NIH images, version 1.61.). Values are presented as mean \pm SEM. Differences were considered statistically significant when ${ }^{*} \mathrm{p}<0.05$.

성이 적은 안전한 물질로 보고한 바(7)와 같이 루꼴라 추출 물이 천연소재로서 피부장벽 기능 향상을 위해 활용가치가 높을 것으로 생각되며, 루꼴라 추출물 성분분석 결과로 플 라보노이드들에 대하여 보고된 바(15)와 같이 항균활성과 피부장벽 기능향상에 플라보노이드 성분들이 활성소재로 서 기능을 나타낸 것으로 사료된다.

\section{요 약}

본 연구에서 루꼴라(Eruca sativa)에 대한 다양한 생리활 성을 조사하여 기능성소재 응용가능성을 검토하였다. 루꼴 라 추출물은 B. subtilis, E. coli, C. albicans에 대한 항균활성 이 매우 우수하게 나타났으며 특히 그람양성세균 B. subtilis 에 대한 항균활성이 높았다. 또한, 인볼루크린 발현에 대한 면역조직화학 분석을 인공피부를 이용하여 분석한 결과 루꼴라 추출물을 처리 $(50 \mathrm{mg} / \mathrm{L})$ 한 경우에 $0.1 \% \mathrm{DMSO}$ 로 처리한 대조군에 비하여 인볼루크린 발현이 뚜렷하게 증가 하였으며 동일농도로 처리된 합성물질 WY14643과 비교하 였을 때에도 비슷한 발현양상을 보여 주었다. 이와 같은 결과로 미루어 볼 때 루꼴라 추출물은 피부염 개선 및 피부 장벽 기능을 향상할 수 있는 천연물 기반의 소재로 활용하 기 위한 매우 효과적인 재료가 될 수 있다고 사료된다.

\section{감사의 글}

본 연구는 2014년도 교육부와 한국연구재단(NRF)의 이 공분야기초연구지원사업의 지원(2014R1A1A2057651)에 의해 수행되었습니다.

\section{References}

1. Elias PM (2005) Stratum corneum defensive functions: an integrated view. J Invest Dermatol, 125, 183-200

2. Holleran WM, Takagi Y, Menon GK, Jackson SM, Lee JM, Feingold KR, Elias PM (1994) Permeability barrier requirements regulate epidermal $\beta$-glucocerebrosidase. $\mathrm{J}$ Lipid Res, 35, 905-912

3. Downing DT (1992) Lipid and protein structures in the permeability barrier of mammalian epidermis. J Lipid Res, 33, 301-313

4. Kuenzli S, Saurat JH (2003) Peroxisome proliferatoractivated receptors in cutaneous biology. Br J Dermatol, 149, 229-236

5. Lamy E, Schroder J, Paulus S, Brenk P, Stahl T, Mersch-Sundermann V (2008) Antigenotoxic properties 
of Eruca sativa (rocket plant), erucin and erysolin in human hepatoma (HepG2) cells towards benzo(a)pyrene and their mode of action. Food Chem Toxicol, 46, 2415-2421

6. Alam MS, Kaur G, Jabbar Z, Javed K, Athar M (2007) Eruca sativa seeds possess antioxidant activity and exert a protective effect on mercuric chloride induced renal toxicity. Food Chem Toxicol, 45, 910-920

7. Kim HS (2016) Anti-melanogenic effect of Eruca sativa extract. Korean J Food Preserv, 23, 74-79

8. Kim B, Choi YE, Kim HS (2014) Eruca sativa and its flavonoid components, quercetin and isorhamnetin, improve skin barrier function by activation of peroxisome proliferator-activated receptor (PPAR)- $a$ and suppression of inflammatory cytokines. Phytother Res, 28, 1359- 1366

9. Herrera-Arellano A, Martinez-Rivera Mde L, HernandezCruz M, Lopez-Villegas EO, Rodriguez-Tovar AV, Alvarez L, Marquina-Bahena S, Navarro-Garcia VM, Tortoriello J (2007) Mycological and electron microscopic study of Solanum chrysotrichum saponin SC-2 antifungal activity on Candida species of medical significance. Planta Med, 73, 1568-1573

10. Jeong GT, Lee KM, Park DH (2006) Study of antimicrobial and antioxidant activities of Rumex crispus extract. Korean Chem Eng Res, 44, 81-86
11. Weber TM, Kausch M, Rippke F, Schoelermann AM, Filbry AW (2012) Treatment of xerosis with a topical formulation containing glyceryl glucoside, natural moisturizing factors, and ceramide. J Clin Aesthet Dermatol, 5, 29-39

12. Jensen JM, Folster-Holst R, Baranowsky A, Schunck M, Winoto-Morbach S, Neumann C, Schutze S, Proksch E (2004) Impaired sphingomyelinase activity and epidermal differentiation in atopic dermatitis. J Invest Dermatol, 122, 1423-1431

13. Kim SH, Nam GW, Lee HK, Moon SJ, Chang IS (2006) The effects of Musk $\mathrm{T}$ on peroxisome proliferatoractivated receptor [PPAR]-a activation, epidermal skin homeostasis and dermal hyaluronic acid synthesis. Arch Dermatol Res, 298, 273-282

14. Wakita H, Takigawa M (1999) Activation of epidermal growth factor receptor promotes late terminal differentiation of cell-matrix interaction-disrupted keratinocytes. J Biol Chem, 274, 37285-37291

15. Nunes TP, Martins CG, Behrens JH, Souza KLO, Genovese MI, Destro MT, Landgraf M (2008) Radioresistance of Salmonella species and Listeria monocytogenes on minimally processed arugula (Eruca sativa Mill.): effect of irradiation on flavonoid content and acceptability of irradiated produce. J Agric Food Chem, 56, 1264-1268 